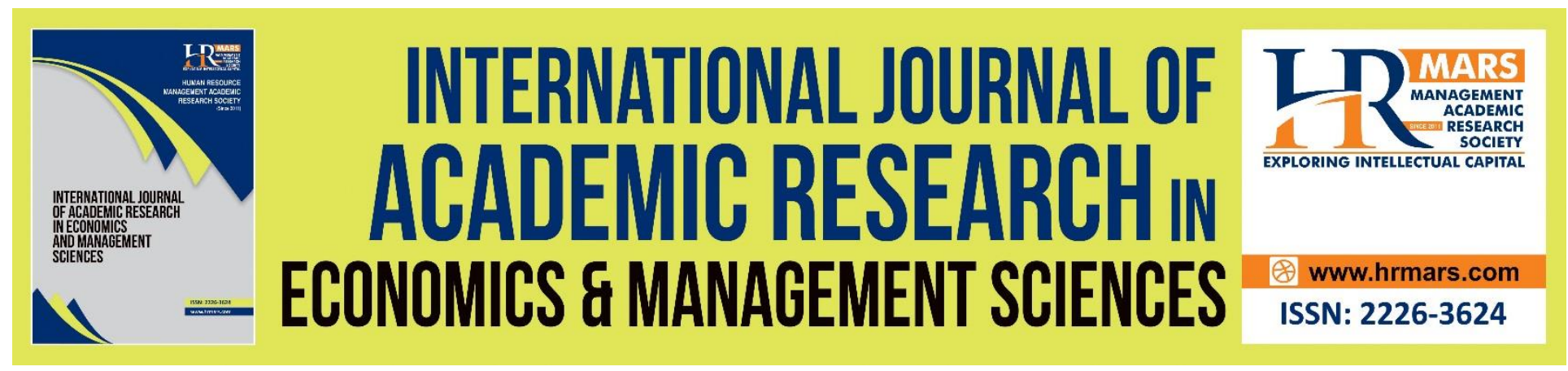

\title{
Impact of External Debt on Economic Growth: The Role of Institutional Quality
}

Teoh Shi Ring, Muhammad Asraf Abdullah, Wan Sofiah Meor Osman, Rosita Hamdan, Josephine Yau Tan Hwang, Abang Azlan Mohamad, Mohd Khairul Hisyam Hassan, Farah Dipah Khalid

To Link this Article: http://dx.doi.org/10.6007/IJAREMS/v10-i3/11054

DOI:10.6007/IJAREMS/v10-i3/11054

Received: 07 June 2021, Revised: 10 July 2021, Accepted: 30 July 2021

Published Online: 14 August 2021

In-Text Citation: (Ring et al., 2021)

To Cite this Article: Ring, T. S., Abdullah, M. A., Osman, W. S. M., Hamdan, R., Hwang, J. Y. T., Mohamad, A. A., Hassan, M. K. H., \& Khalid, F. D. (2021). Impact of External Debt on Economic Growth: The Role of Institutional Quality. International Journal of Academic Research in Economics and Management and Sciences, 10(3), 223-236.

Copyright: ( 2021 The Author(s)

Published by Human Resource Management Academic Research Society (www.hrmars.com)

This article is published under the Creative Commons Attribution (CC BY 4.0) license. Anyone may reproduce, distribute, translate and create derivative works of this article (for both commercial and non-commercial purposes), subject to full attribution to the original publication and authors. The full terms of this license may be seen

at: http://creativecommons.org/licences/by/4.0/legalcode

Vol. 10, No. 3, 2021, Pg. 223 - 236

http://hrmars.com/index.php/pages/detail/IJAREMS

JOURNAL HOMEPAGE

Full Terms \& Conditions of access and use can be found at http://hrmars.com/index.php/pages/detail/publication-ethics 


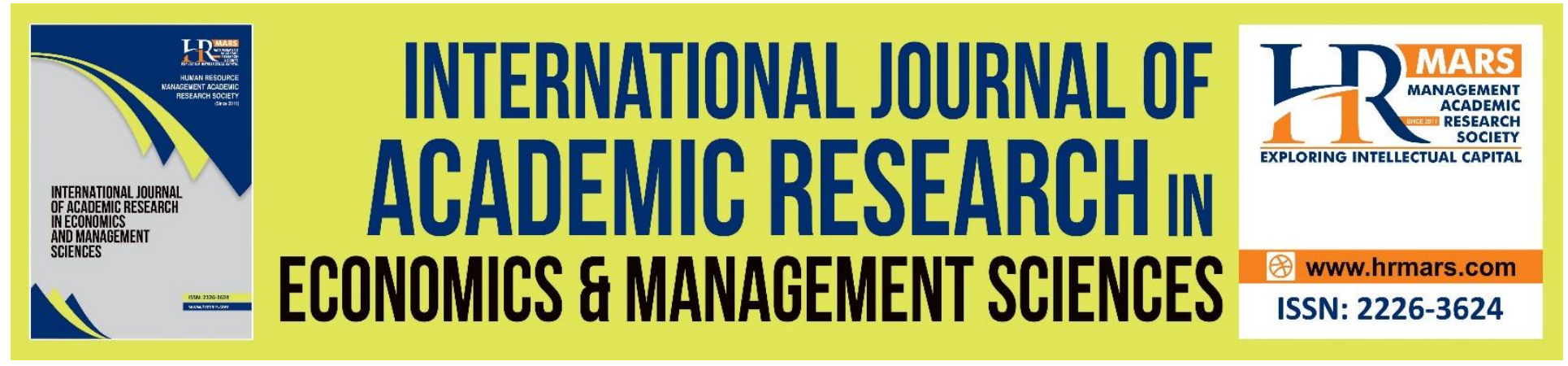

\title{
Impact of External Debt on Economic Growth: The Role of Institutional Quality
}

\author{
Teoh Shi Ring, Muhammad Asraf Abdullah, Wan Sofiah Meor \\ Osman, Rosita Hamdan, Josephine Yau Tan Hwang, Abang \\ Azlan Mohamad, Mohd Khairul Hisyam Hassan, Farah Dipah \\ Khalid
}

Faculty of Economics and Business, Universiti Malaysia Sarawak, 94300 Sarawak, Malaysia.

Email: amasraf@unimas.my

\begin{abstract}
Utilizing GMM panel data analysis, covering twenty-three samples of countries from 2011 to 2014, this study examines the nexus between external debt and economic growth where institutional quality acts as a moderator. The samples for the study are divided into two groups consisting of low and high governance groups of countries. Findings report the importance of institutional quality as a moderator in the relationship between external debt and economic growth for both samples of study. The results confirm that, despite the importance of good governance practices, as indicated by the significant effect of high scores in governance indicators such as voice and accountability (samples from low governance countries) and regulatory quality (samples from high governance countries), prescribing the right policy is crucial to avoid the negative impact of the wrong policy prescription on economic growth. The results are dissected into two groups, for low governance and high governance countries respectively. Overall, the study suggests good debt management and feasible policy prescriptions are the keys to controlling external debt.
\end{abstract}

Keywords: External Debt, Governance, Institutional quality, Economic Growth, Generalized Method of Moments

\section{Introduction}

Over the last decade, statistics show a dramatic increase in external debt in most developing countries, where external debt remains high as a proportion of gross domestic product (GDP). Rapid economic development experienced by developing countries has resulted in an increase in demand for external debt to finance various investment expenditures, including infrastructure and other investments. However, this requires sustainable external debt to avoid negative impacts on the economy, such as falling foreign investment and currency devaluation, which hampers economic growth. Previous studies reported direct proportional relationship 
between external debt and economic growth (Balago, 2014; Zaman \& Arslan, 2014). The high level of external debt has a detrimental impact on economic growth, as explicated by the overhang hypothesis and liquidity constraints (Arnone, Bandiera, and Presbitero, 2005). For instance, during the European debt crisis, 2008/2009, countries such as Greece, Portugal, Ireland, Italy and Spain overestimated their capability to pay back debt interest payments after accumulating large amounts of external debt, which suggests the failure of countries' governance and debt management. These countries are nearly facing bankruptcy due to failure to pay back their debt

Huge debt is not only a problem for developed as well as developing countries. For example, some developing countries have faced external debt issue owing to its currency problem (Bryson \& Nelson, 2014). This is because most of the developing countries have weak currency. For instance, developing countries like Thailand, Malaysia and China have increased their external debt to boost their economic growth during the Global Financial Crisis 2008/2008. The depreciation of the currency causes the value of external debt repayment to increase during the period of borrowing. Despite currency depreciation, the economic growth of the country has shown an increasing trend, which is useful for paying back the external debt (Atique \& Malik, 2012).

Good macroeconomic and efficient debt management are the keys to overcoming the external debt problem. Despite many studies carried out to investigate the impact of external debt on economic growth in different countries, however, there is less attention paid to examining the influence of country's governance as a moderator in the relationship between external debt and economic growth. This study serves two objectives. Firstly, to review the external debt position of the selected countries. Secondly, to compare the impact of external debt on economic growth in low governance and high governance countries.

\section{Trend of External Debts for Low and High Governance Countries.}

To understand the issue behind huge external debt, it is worth exploring the trend of external debts for both low governance and high governance countries as presented in figure 1. Figure 1 shows the total external debt stocks in low governance and high governance countries for a period from 2005 until 2014. A total of 23 countries have been observed for the purpose of observation. These countries are divided into two categories which are low governance and high governance countries. The division of low and high governance countries is decided by taking the median score of average governance indicators obtained from the Worldwide Governance Indicators. Based on the median score categorization approach, a total of 12 countries were grouped as low governance countries which are Pakistan, Philippines, Mexico, Indonesia, Nigeria, Thailand, Ukraine, Uganda, Malawi, Ghana, Zambia and Colombia. Whilst the high governance countries included Malaysia, Portugal, Spain, Greece, Germany, Canada, Luxembourg, Poland, United Kingdom, United States and Switzerland. 
Figure 1: Total External Debt Stocks for Low and High Governance Countries, 2005-2014

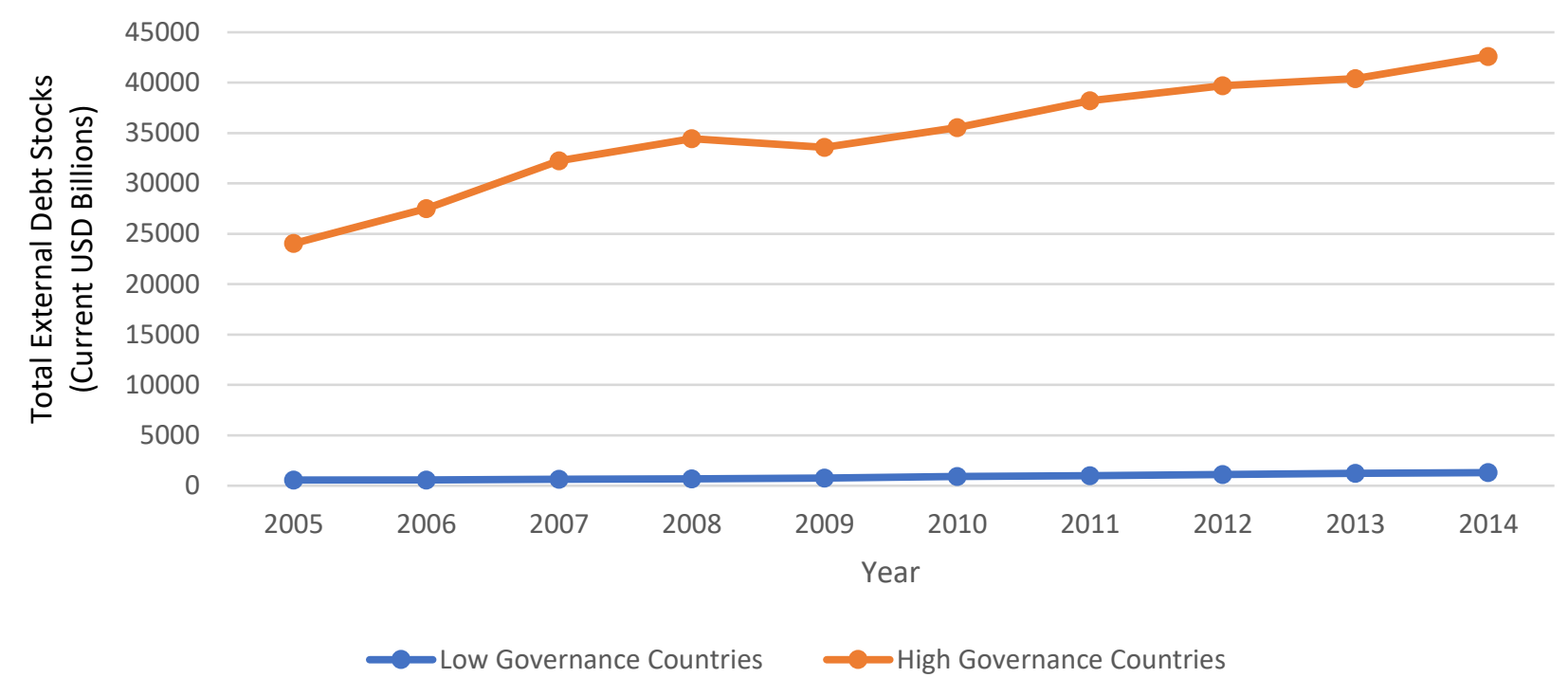

There are a few reasons that explain the increasing trend of external debt in the sample of both low-governance and high-governance countries throughout the observed period from 2004 to 2014. External debts remained constant during a period from 2005 to 2006 for low governance countries. The total external debt for low governance countries is mostly adjusted by economic liquidity and foreign exchange reform. In 2009, foreign exchange revaluation of US dollar led to rising external debt by $19.35 \%$ amounting from $\$ 755.2$ billion in 2009 to $\$ 901.3$ billion in 2010. Since then, the external debt for low governance countries has increased persistently until 2014.

For high governance countries, most countries recorded a significant increase of external debt from 2004 to 2008 except for Switzerland. The total external debt for Switzerland fell from \$111.4 billion in 2007 to $\$ 897.6$ billion in 2008 due to the reduction of Switzerland's interbank liabilities (Swiss National Bank Statistic, 2011). However, this trend reversed in 2009 where the total external debt in high governance countries dropped by $2.54 \%$ due to the Global Financial Crisis. The total external debt has regained in year 2010 and has since continually rose until 2014.

Overall, figure 1 indicates a significant increase in the external debt levels for low governance and high governance countries during the period from 2005 to 2014, which drew our attention to investigate the reasons behind persistent increases in external debt for both categories of countries. Previous studies have mostly focused on developing countries, while less attention has been paid on the developed countries. Developed countries are worth investigating considering the issue of serious deficits encountered by the Eurozone in the global financial crisis of 2007/2008. Moreover, previous studies only investigate the direct relationship between external debt and economic growth which includes other macroeconomics variables as the control variables without investigating the moderating impact of governance in the relationship between the external debt and economic growth. Thus, this study helps to increase understanding of external debt and economic growth relationships in the presence of institutional factors. 


\section{Literature Review}

There are two theories that are closely related to the impact of external debt on economic growth namely the Lerner Theory and Debt Overhang Theory. The Lerner theory explains that contractionary effect if taxes are raised to service the debt (Lerner, 1948). In other word, government will increase tax to pay back the debt if the country encountered deficit budget. Meanwhile, Debt Overhang theory concerned about current and future cash flow that affect a country's decision of borrowing (Myers, 1977). Debt overhang occurs when a debtor country does not have the ability to make debt repayment.

Over the past decades, there has been an increasing amount of literature on the topic of external debt and growth. For example, a study conducted by Atique and Malik (2012) who examined the impact of external debt on Pakistan's economy over the period between 1980 to 2010. The study findings showed a negative impact of external debt on economic growth and slowing down of economic growth as compared to domestic debt due to currency problem. Besides that, studies of Babu et al (2014); Zouhaier and Fatma (2014) and Qayyum and Haider (2012) also highlighted similar result in which external debt has a negative effect on economic growth in East African Community.

However, studies by Nurazira et al (2012) reveal contrasting views. According to the study, Malaysia's economic growth increases with the increase in external debt up to an optimal point. The study results reveal an adverse relationship between external debt and economic growth in Malaysia after exceeding the optimal point. External debt is found to have a negative effect on economic growth in Malaysia as investment has not been allocated efficiently. Another study by Nwannebuike, Ike and Onuka (2016) in Nigeria highlighted similar findings to the study of Nurazira et al (2012) which argues a positive relationship between external debt and economic growth in the short run but a negative in the long run.

The next study by Uzun et al (2012) suggests a negative effect of debt on the growth rate of transition countries in the short run, but a positive relationship in the long run. This finding was supported by Jilenga, Xu and Igor (2016), who used ARDL and Bound tests on a sample of Tanzanians from 1971 to 2011 to show a positive association between external debt and economic growth in the long run.

Fayissa and Nsiah (2013) extend their analysis beyond the scope of Uzun et al (2012), where they found that good governance had a positive and significant impact on growth in 28 sub-Saharan African countries during the period from 1990 until 2004. According to the report, strong governance is critical for the economic growth of Sub-Saharan African nations, particularly those at the lower end of the income distribution spectrum. Besides that, Emara and Jhonsa (2014) applied two stage least square regression to determine the nexus between governance and economic growth in 197 Middle East and North Africa (MENA) countries in 2009. The result also showed that impact of governance on economic growth was positive and statistically significant.

Bayar (2016) also suggest the importance of good governance for sustainable economic growth because all governance indicators except regulatory quality had a statistically positive impact on economic growth in 11 transitional EU countries from 2002 until 2013. In 11 transitional EU countries, corruption control and rule of law had the greatest impact on economic growth, while political stability had the least impact. Besides that, Qayyum and Haider (2012) also took the consideration of governance in their study for 60 samples of development countries 
from 1984 to 2008. The study findings suggested that developing countries should focus on addressing governance issues because good governance is crucial for growth in low income countries.

A few studies have focused on the role of institutions in explaining the relationship between external debt and growth. For example, a study of Atique et al. (2012) applied corruption index as one of the independent variables to indicate the impact of external debt on economic growth in Pakistan. The result revealed that corruption does not affect economic growth. However, Kim et al (2017) showed debt enhances growth in countries that have a high transparency score. Another study conducted by Jalles (2011) also found a positive and negative impact of debt on growth, although the countries had lower corruption. He suggested that for countries with a low level of corruption, the government should implement the HIPC Initiative and extend additional disbursements as debt has an adverse effect on growth.

In sum, past studies have showed mixed results pertaining to the relationship between external debt and the economic growth. Most studies show a negative impact of external debt on economic growth due to investment crowding out effects and debt service. However, the role of good governance is not deniable when facing the issue of high external debt as it plays an important role in enhancing economic growth (Kim, Ha \& Kim, 2017).

\section{Methodology \\ Data Description}

This study intends to investigate the impact of external debt on economic growth in low governance and high governance countries from 2011 to 2014. The variables involved are real gross domestic product (GDP) as the dependent variable, and external debt ratio (EDR), imports (M), governance indicators (GOV) and the interaction between governance indicators and external debt (GOV*ED) as independent variables. The data is sourced from the World Bank Indicator via the World Bank and CEIC databases. The samples of study consist of 23 countries, which are divided into low-governance and high-governance countries. The low governance countries sample included Pakistan, Philippines, Mexico, Indonesia, Nigeria, Thailand, Ukraine, Uganda, Malawi, Ghana, Zambia, and Colombia. While the sample for high-governance countries includes Malaysia, Portugal, Spain, Greece, Germany, Canada, Luxembourg, Poland, the United Kingdom, the United States and Switzerland.

The measurement for governance level of the countries follows the dataset obtained from the Worldwide Governance Indicators (WGI). According to WGI, governance is measured in terms of six dimensions including voice and accountability, political stability and absence of violence, government effectiveness, regulatory quality, rule of law and control of corruption. The division of countries into low and high governance is done by taking the median score of each average governance index. Countries that score lower than the median score in governance are considered as low governance groups. While countries that recorded governance scores higher than the calculated median score are considered as high governance groups.

\section{Model Specification}

The relationship between external debt and economic growth can be explained by the debt overhang theory introduced by Krugman (1988) and Sachs (1989). According to the theory, the ability of a debtor country to service its stock of debts increases with a rise in the size of its 
debts, and the repayment ability reaches its maximum and will fall after an optimal debt size is reached. This relationship can be modelled as in equation (1).

$$
Y_{t}=f\left(E D R_{t}\right)
$$

where, $Y$ is real gross domestic product, and EDR is external debt ratio.

Considering many factors that influence the economic growth besides the variable of our interest which is external debt, in this study we test the moderating role of institutional quality in affecting the relationship between external debt and economic growth. The model in equation (1) is extended to equation (2) to cover various institutional quality indicators as a set of moderators including other control variables commonly used in past studies. Thus, the model in equation 1 is modified and written as in equation (2).

$$
Y_{t}=f\left(E D R_{t}, M_{t}, G O V_{t}, G O V^{*} E D R_{t}\right)
$$

In this model, GOV consists of a set of governance indicators (as measured by World Governance Indicators), which are voice and accountability, control of corruption, political stability, no violence, government effectiveness, regulatory quality, and the rule of law. The moderating effect of institutional quality is measured by the interaction between each of the six components of governance indicators and external debt, GOV*ED.

The function in equation (2) is converted to a panel form of economic equation as shown in equation (3).

The variables $Y_{t}, E D R_{t}, M_{t}$ are expressed in logarithms form to avoid bias.

$\log \left(Y_{i t}\right)=b_{0}+b_{1} \log \left(Y_{i, t-1}\right)+b_{2} \log \left(E D R_{i t}\right)+b_{3} \log \left(M_{i t}\right)+b_{3} G O V_{i t}+b_{5} G O V^{*} E D R_{i t}+\mu_{i}+v_{t}+\varepsilon_{i t}$

where $i=1,2, \ldots, 23$ and $t=1,2, \ldots, 4$.

where, $Y_{i t}$ is real gross domestic product for country $i$ at period $t, Y_{i, t-1}$ is lagged value of dependent variable, $E D R_{i t}$ is external debt ratio for country $i$ at period $t, M_{i t}$ is import for country $i$ at period $t, G O V_{i t}$ is a set of governance indicators that includes voice and accountability, control of corruption, political stability no violence, government effectiveness, regulatory quality, and rule of law for country $i$ at period $t, G O V^{*} E D R_{i t}$ is the interaction of governance indicator and external debt ratio for country $i$ at period $t, b_{1}, b_{2}, b_{3}, b_{4}$ is the parameter, $\mu_{i}$ is a country-specific effect, $v_{t}$ is a time-specific effect $\varepsilon_{i t}$ is common error term. The expected sign for $B_{1}$ which denotes external debt should be negative based on debt overhang theory (Zouhaier \& Fatma, 2014; Nwannebuike, Ike \& Onuka 2016). However, positive impact of external debt on economic growth might happened if the country has the good quality of governance, adequate debt management, diversified export base and fiscal revenue mobilization (Sun, 2004).

\section{Estimation Technique}

The dynamic panel data analysis based on the Generalized Method of Moments (GMM) estimation technique is used to investigate the impact of external debt sustainability on economic growth in low governance and high governance countries. The GMM estimator was first introduced by Hansen (1982) and further developed by Holtz-Eakin, Newey and Rosen (1988), Arellano and Bover (1995), Arellano and Bond (1991) and Blundell and Bond (1998). The GMM estimators are used to exploits the dynamic relationships inherent in explanatory variables.

System GMM (Blundell and Bond, 1998) is used to highlight the issues of endogeneity and potential bias that arise from time-invariant unobserved heterogeneity. When the time period 
dimension, $\mathrm{T}$, is short, the relevance of utilising the initial condition in developing effective estimators of dynamic panel data models is underlined. The following is a simple autoregressive panel data model with no exogenous regressors:

$$
y_{i t}=\delta y_{i, t-1}+\mu_{i}+v_{i t}
$$

with $E\left(\mu_{i}\right)=0, E\left(v_{i t}\right)=0, E\left(\mu_{i} v_{i t}\right)=0$ for $i=1,2, \ldots, \mathrm{N}$ and $t=1,2, \ldots, \mathrm{T}$.

The starting conditions process was shown to have an extra mild stationary limitation by system GMM, permitting the application of an extended system GMM that uses lagged differences in $y_{i t}$ as instruments for equations in levels. The approach also outperforms basic firstdifferences GMM in terms of efficiency, demonstrating that level limitations are still useful in circumstances when first differences instruments are weak.

\section{Results and Discussions}

The results of the GMM regression analysis are reported in Table 1. The GMM model is adequate because the lagged RGDP is positive and statistically significant at the $5 \%$ significance level, which indicates that the past RGDP has positively affected the present RGDP. The results indicate that external debt is statistically significant and has a negative impact on economic growth as indicated by the results for models 1-6 in Table 1. This finding is in line with the debt overhang theory, where the theory considers the disincentive effects of government policies and investment channels have a negative effect on growth because return gains from investment are taxed away by foreign creditors. However, when the effect of institutional quality, which is proxied by the six dimensions of governance indicators, is considered, external debt is found insignificant except for model 1 where the moderator is proxied by voice and accountability. In addition, this result is supported by empirical findings from past studies, for example Atique and Malik (2012), Babu et al. (2014), Zouhaier and Fatma (2014), and Qayyum and Haider (2012).

The current study also found that import as a control variable is significant and has a positive relationship with RGDP. This finding was expected as import plays a critical role in embodied new knowledge and technologies like machines (Grossman and Helpman, 1991; Thangavelu \& Rajaguru, 2004). Overall, the Sargan test for overidentification does not reject the null hypothesis in low governance countries. This concludes that the instruments in the study are valid. 
INTERNATIONAL JOURNAL OF ACADEMIC RESEARCH ECONOMICS AND MANAGEMENT SCIENCES Vol. 10 , No. 3, 2020, E-ISSN: 2226-3624 ㄷ 2020 HRMARS

Table 1: System GMM Estimates of External Debt Impact on Economic Growth for Low Governance Countries

\begin{tabular}{|c|c|c|c|c|c|c|}
\hline Variables & Model 1 & Model 2 & Model 3 & Model 4 & Model 5 & Model 6 \\
\hline $\operatorname{Lrgdp}_{(t-1)}$ & $\begin{array}{c}0.2951^{* *} \\
(3.08)\end{array}$ & $\begin{array}{c}0.2495^{* *} \\
(2.52)\end{array}$ & $\begin{array}{c}0.3057^{* *} \\
(2.58)\end{array}$ & $\begin{array}{c}0.2805^{* *} \\
(2.52)\end{array}$ & $\begin{array}{c}0.2452^{* *} \\
(3.12)\end{array}$ & $\begin{array}{c}0.2583^{* *} \\
(2.78)\end{array}$ \\
\hline Ledr & $\begin{array}{c}-0.2310^{* *} \\
(-4.05)\end{array}$ & $\begin{array}{c}-0.2568 * * \\
(-2.91)\end{array}$ & $\begin{array}{c}-0.2399 * * \\
(-3.51)\end{array}$ & $\begin{array}{c}-0.3644^{* *} \\
(-4.95)\end{array}$ & $\begin{array}{c}-0.2541^{* *} \\
(-3.70)\end{array}$ & $\begin{array}{c}-0.2217^{* *} \\
(-2.86)\end{array}$ \\
\hline $\mathrm{Lm}$ & $\begin{array}{c}0.8129 * * \\
(8.20)\end{array}$ & $\begin{array}{c}0.8527^{* *} \\
(8.04)\end{array}$ & $\begin{array}{c}0.8006^{* *} \\
(6.37)\end{array}$ & $\begin{array}{c}0.8195^{* *} \\
(7.31)\end{array}$ & $\begin{array}{c}0.8525^{* *} \\
(9.88)\end{array}$ & $\begin{array}{c}0.8416^{* *} \\
(8.58)\end{array}$ \\
\hline Vna & $\begin{array}{c}0.2306 \\
(1.16)\end{array}$ & & & & & \\
\hline Edrvna & $\begin{array}{c}-0.0079 * * \\
(-1.94)\end{array}$ & & & & & \\
\hline Coc & & $\begin{array}{c}-0.1090 \\
(-0.64)\end{array}$ & & & & \\
\hline Edrcoc & & $\begin{array}{c}0.0016 \\
(0.67)\end{array}$ & & & & \\
\hline Ps & & & $\begin{array}{c}0.0019 \\
(0.02)\end{array}$ & & & \\
\hline Edrps & & & $\begin{array}{c}0.0006 \\
(0.61) \\
\end{array}$ & & & \\
\hline Gef & & & & $\begin{array}{c}0.2434 \\
(1.28)\end{array}$ & & \\
\hline Edrgef & & & & $\begin{array}{c}-0.0068 \\
(-1.60) \\
\end{array}$ & & \\
\hline $\mathbf{R q}$ & & & & & $\begin{array}{l}-0.0514 \\
(-0.26)\end{array}$ & \\
\hline Edrrq & & & & & $\begin{array}{l}0.0019 \\
(0.73)\end{array}$ & \\
\hline Rol & & & & & & $\begin{array}{c}-0.2184 \\
(-1.23)\end{array}$ \\
\hline Edrrol & & & & & & $\begin{array}{c}0.0027 \\
(0.95) \\
\end{array}$ \\
\hline $\begin{array}{l}\text { Number of } \\
\text { instruments }\end{array}$ & 10 & 10 & 10 & 10 & 10 & 10 \\
\hline $\begin{array}{l}\text { Number of } \\
\text { groups }\end{array}$ & 12 & 12 & 12 & 12 & 12 & 12 \\
\hline $\begin{array}{l}\text { Sargan test } \\
\text { (p-value) }\end{array}$ & 0.1689 & 0.1578 & 0.2818 & 0.7899 & 0.1650 & 0.2849 \\
\hline
\end{tabular}

Notes: The dependent variable is real GDP. Independent variables include external debt ratio, import, governance proxies and interaction between external debt ratio and governance proxies. Figure in parentheses are the t-statistic value. Asterisks $(* *, *)$ indicate statistically significant at $5 \%$ and $10 \%$ significance level. 
INTERNATIONAL JOURNAL OF ACADEMIC RESEARCH ECONOMICS AND MANAGEMENT SCIENCES Vol. 10 , No. 3, 2020, E-ISSN: 2226-3624 ㄷ 2020 HRMARS

Table 2 presents the impact of external debt on economic growth in high governance countries based on system GMM estimation. In high governance countries, external debt shows negative nexus and statistically significant result on economic growth except for model 1, 2 and 5. Meanwhile, import also act as an important role in high governance countries to promote the countries' growth as it also showed significant and a directly proportional nexus towards RGDP. As expected, lagged RGDP for all six models is positive and statistically significant at the $5 \%$ significance level, suggesting previous RGDP had positively influenced current RGDP. Furthermore, the Sargan J test for all models is greater than 5 percent significance level except for model 3, which implies that the instruments are valid for most models.

Table 2: System GMM Estimates of External Debt Impact on Economic Growth for High Governance Countries

\begin{tabular}{|c|c|c|c|c|c|c|}
\hline Variables & Model 1 & Model 2 & Model 3 & Model 4 & Model 5 & Model 6 \\
\hline $\operatorname{Lrgdp}_{(t-1)}$ & $\begin{array}{c}0.2317^{* *} \\
(2.85)\end{array}$ & $\begin{array}{c}0.2867^{* *} \\
(2.83)\end{array}$ & $\begin{array}{c}0.2715^{* *} \\
(2.70)\end{array}$ & $\begin{array}{c}0.2846^{* *} \\
(3.53)\end{array}$ & $\begin{array}{c}0.2711^{* *} \\
(2.92)\end{array}$ & $\begin{array}{c}0.2602^{* *} \\
(3.08)\end{array}$ \\
\hline Ledr & $\begin{array}{c}-0.1590 \\
(-1.45)\end{array}$ & $\begin{array}{c}-0.1945 \\
(-1.59)\end{array}$ & $\begin{array}{c}-0.2260 * * \\
(-2.04)\end{array}$ & $\begin{array}{c}- \\
0.2615^{* *} \\
(-2.84)\end{array}$ & $\begin{array}{c}-0.1545 \\
(-1.24)\end{array}$ & $\begin{array}{c}-0.3740 * * \\
(-4.25)\end{array}$ \\
\hline $\mathrm{Lm}$ & $\begin{array}{c}0.6682^{* *} \\
(7.47) \\
\end{array}$ & $\begin{array}{c}0.6538^{* *} \\
(6.16) \\
\end{array}$ & $\begin{array}{c}0.6506^{* *} \\
(5.91) \\
\end{array}$ & $\begin{array}{c}0.5611^{* *} \\
(6.47)\end{array}$ & $\begin{array}{c}0.6637^{* *} \\
(6.01) \\
\end{array}$ & $\begin{array}{c}0.5222^{* *} \\
(5.51)\end{array}$ \\
\hline Vna & $\begin{array}{c}-0.3220^{* *} \\
(-2.56)\end{array}$ & & & & & \\
\hline Edrvna & $\begin{array}{c}-0.0000 \\
(-1.38) \\
\end{array}$ & & & & & \\
\hline Coc & & $\begin{array}{c}-0.0210 \\
(- \\
0.30)\end{array}$ & & & & \\
\hline Edrcoc & & $\begin{array}{c}-0.0000 \\
(- \\
1.12) \\
\end{array}$ & & & & \\
\hline Ps & & & $\begin{array}{c}-0.0380 \\
(-0.51)\end{array}$ & & & \\
\hline Edrps & & & $\begin{array}{c}-0.0000 \\
(-1.06)\end{array}$ & & & \\
\hline Gef & & & & $\begin{array}{c}0.1799 * * \\
(2.69)\end{array}$ & & \\
\hline Edrgef & & & & $\begin{array}{c}-0.0000 \\
(-1.25)\end{array}$ & & \\
\hline $\mathbf{R q}$ & & & & & $\begin{array}{c}0.1043 \\
(1.45)\end{array}$ & \\
\hline Edrrq & & & & & $\begin{array}{c}-0.0000^{*} \\
(-1.72)\end{array}$ & \\
\hline Rol & & & & & & $0.1915^{* *}$ \\
\hline
\end{tabular}


INTERNATIONAL JOURNAL OF ACADEMIC RESEARCH ECONOMICS AND MANAGEMENT SCIENCES Vol. 10, No. 3, 2020, E-ISSN: 2226-3624 @ 2020 HRMARS

\begin{tabular}{lcccccc}
\hline & \multicolumn{7}{l}{} & & & & $(2.43)$ \\
\hline Edrrol & 10 & 10 & 10 & 10 & 10 & $\begin{array}{c}-0.0000 \\
(-0.49)\end{array}$ \\
\hline $\begin{array}{l}\text { Number of } \\
\text { instruments }\end{array}$ & 11 & 11 & 11 & 11 & 11 & 11 \\
\hline $\begin{array}{l}\text { Number of } \\
\text { groups }\end{array}$ & 11 & 0.0863 & $0.0429 * *$ & 0.0666 & 0.1555 & 0.0614 \\
\hline $\begin{array}{l}\text { Sargan test } \\
\text { (p-value) }\end{array}$ & 0.2742 & & & & & \\
\hline
\end{tabular}

Notes: The dependent variable is real GDP. Independent variables include external debt ratio, import, governance proxies and interaction between external debt ratio and governance proxies. Figure in parentheses are the t-statistic value. Asterisks $(* *, *)$ indicate statistically significant at $5 \%$ and $10 \%$ significance level.

Overall, external debt showed a negative and significant relationship with economic growth for all models from the samples of low governance countries, but only for models 3,4 and 6 for the samples of high governance countries. Initially, the finding for model 5 from high governance countries sample does not showed a significant relationship between external debt and economic growth. However, when institutional quality as proxied by regulatory quality was introduced as a moderator, in model 5, the result indicates a significant and negative impact of external debt on economic growth. This empirical finding suggests that high levels of external debt, as indicated by high regulatory quality in the sample of high governance countries, tend to pull economic growth down, which is in line with a finding by Giannone et al (2010) that regulatory quality in terms of policies that favour liberalisation of the credit market, such as interest rate control, is negatively correlated with economic growth during recession. For example, during the economic recovery period, after the global economic recession in 2008/2009, some European countries took drastic actions to stabilise their economies. These include drastic changes made in sectoral regulations which focus on services liberalisation, the digital economy, and the business environment in order to enhance the market conditions. Those policy reform has met with a failure in raising the nations' economic growth. For instance, an action pursued by Greece to reform the labour market through reduction of labour costs and pensions has resulted in the introduction of a new property tax which has burdened the lower income groups in the country (Kyriakopoulos, 2014).

Besides that, imports showed a positive and significant effect on economic growth in both samples set from low and high governance countries. However, the coefficient of import for low governance countries is larger than the coefficient of import for high governance countries. It can be concluded that import-led growth impacts are more for low-governance countries than for high-governance countries through the flow of foreign technology and knowledge which promotes growth.

\section{Conclusion}

This study was carried out to determine the impact of external debt on growth in the presence of institutional quality. It applies the System GMM estimation technique on a dataset 
consists of 23 countries from 2011 to 2014. The findings suggest a direct negative impact of external debt on the economic growth for the samples from low governance countries. Nonetheless, the result for the sample from high governance countries reported significant relationship between external debt and economic growth for 3 of the 6 models estimated. Furthermore, a control variable which is import is found to be statistically significant and positively affect growth in both low governance and high governance countries through knowledge and technology absorption. In addition, the findings show that the interaction between external debt and regulatory quality is statistically significant. This indicates that regulatory quality moderates the relationship between external debt and growth but in a negative direction.

This study highlights the importance of institutional quality in determining the effect of debt policies when addressing the issue of surmounting external debt. The results showed that countries with high external debt may face a detrimental impact on economic growth despite good governance practices of high regulatory quality. The findings from this study suggest that, despite practising good governance, a country must ensure that the policies prescribed to overcome the issue of huge external debt are feasible and efficient. For example, one of the policies suggested by the IMF to recover from slow economic growth during the European Debt Crisis was through the reduction of government expenditure. This recommendation has been misinterpreted by European countries through a deep cut in government expenditures by wrongly focusing on labour market adjustment, which further worsens the economic growth of countries in the union. Although budget reduction is one of the solutions to control debt, it has to be carefully considered to avoid a negative impact on the overall economy. Good external debt management is essential to achieve debt sustainability.

One of the suggestions is that the government may reverse its focus on expenditure reduction in the labour market by drawing more attention to other variables, like subsidy adjustment etc. For example, the government needs to ensure only important subsidies that have a long-term impact on the economy, such as protecting the infant industry to help it boost its competitiveness, and social policy measures to develop indigeneous industries where the initial capital outlay is too large for the industry to finance by itself, as well as subsidies targeting the poorest segment of the population. These measures will ensure that all the funds secured through external debt are used for productive investments which have a positive long term impact on economic growth. This study has a limit in terms of the number of variables tested in the models due to an insufficient period of observation. This issue could be overcome in the future by extending the period of study to accommodate more variables which are deemed important for the study.

\section{Acknowledgement}

The authors acknowledge University Malaysia Sarawak, Special MyRA Assessment Funding, F01/SpMYRA/1688/2018 for supporting this project.

\section{References}

Al-Bassam, B. A. (2013). The Relationship between Governance and Economic Growth during Times of Crisis. European Journal of Sustainable Development, 2(4), 1-18. 
Arellano, M., \& Bover, O. (1991). Some Tests of Specification for Panel Data: Monte Carlo Evidence and an Application to Employment Equations. The Review of Economic Studie, 58(2), 277.

Arellano, M., \& Bover, O. (1995). Another Look at the Instrumental Variable Estimation of ErrorComponents Models. Journal of Economtrics, 68(1), 29-51.

Arnone, M., Bandiera, L., \& Presbitero, A. F. (2005). External Debt Sustainability: Theory and Empirical Evidence. Retrieved from http://econwpa.repec.org/eps/if/papers/0512/0512007.pdf

Atique, R., \& Malik, K. (2012). Impact of Domestic and External Debt on the Economic Growth of Pakistan. World Applied Sciences Journal, 20(1), 120-129.

Babu, J. O., Kiprop, S., Kalio, A. M., \& Gisore, M. (2014). External Debt and Economic Growth in the East Africa Community. African Journal of Business Management, 8(21), 1011-1018.

Balago, G. S. (2014). An Empirical Analysis of the Relationship between Government External Borrowings and Economic Growth in Nigeria. International Journal of Finance and Accounting, 3(4), 235-243.

Bayar, Y. (2016). Public Governance and Economic Growth in the Transitional Economies of the European Union. Transylvanian Review of Administrative Sciences, 48, 5-18.

Blundell, R., \& Bond, S. (1998). Initial Conditions and Moment Restrictions in dynamic panel data models. Journal of Econometrics, 87, 115-143.

Bryson, J. H., \& Nelson, E. (2014). Which Countries Have External Debt "Issues"? Wells Fargo Securities Economics Group. Retrieved from http://www.realclearmarkets.com/docs/2014/12/External\%20Debt\%20_\%20Dec\%202014. pdf

Emara, N., \& Chiu, I-M. (2016). The Impact of Governance on Economic Growth: The Case of Middle Eastern and North African Countries. Topics in Middle Eastern and African Economics, 18(1), 126-144.

Emara, N., \& Jhonsa, E. (2014). Governance and Economic Growth: Interpretations for MENA Countries. Topics in Middle Eastern and African Economies, 16(2), 164-183

Fayissa, B., \& Nsiah, C. (2013). The Impact of Governance on Economic Growth in Africa. The Journal of Developing Areas, 47(1), 91-108.

Giannone, D., Lenza, M., \& Reichlin, R. (2010). Market Freedom and the Global Recession. IMF Economic Review, Palgrave Macmillan; International Monetary Fund, 59(1), 111-135.

Grossman, G. M., \& Helpman, E. (1991). Innovation and Growth in The Global Economy. Cambridge: MIT Press.

Hansen, L. (1982). Large Sample Properties of Generalized Method of Moments Estimators. Econometrica, 50(4), 1029-1054.

Holtz-Eakin, D., Newey, W., \& Rosen, H. (1988). Estimating Vector Autoregressions with Panel Data. Econometrica, 56(6), 1371-1395.

Jalles, J. T. (2011). The Impact of Democracy and Corruption on the Debt-Growth Relationship in Developing Countries. Journal of Economic Development, 36(4), 41-72

Kim, E., Ha, Y., \& Kim, S. (2017). Public Debt, Corruption and Sustainable Economic Growth. Sustainability, 9, 1-30.

Krugman, P. (1988). Financing versus forgiving a debt overhang. NBER Working Paper 2486. 
INTERNATIONAL JOURNAL OF ACADEMIC RESEARCH ECONOMICS AND MANAGEMENT SCIENCES

Vol. 10 , No. 3, 2020, E-ISSN: 2226-3624 ㄷ 2020 HRMARS

Kyriakopoulos, I. (2014). In the Name of the Euro: What Have the EU's Policies Achieved in Greece? Intereconomics, 49(6), 332-338.

Lerner, A. P. (1948). "The Burden of the National Debt," in Lloyd A. Metzler et al. (eds.), Income, Employment and Public Policy, Essays in Honour of Alvin Hanson. W. W. Norton, New York. 255-275.

Myers, S. C. (1977). Determinants of Corporate Borrowing. Journal of Financial Economics, 5(2), 147-175.

Nwannebuike, U. S., Ike, U. J., \& Onuka, I. O. (2016). External Debt and Economic Growth: The Nigeria Experience. European Journal of Accounting Auditing and Finance Research. 4(2), 3348.

Pere, E. (2015). The Impact of Good Governance in the Economic Development of Western Balkan Countries. European Journal of Government and Economics, 4(1), 26-45.

Qayyum, U., \& Haider, A. (2012). Foreign Aid, External Debt and Economic Growth Nexus in LowIncome Countries: The Role of Institutional Quality, 1(22), 97-115.

Sachs, J. (1989). The debt overhang of developing countries. In Calvo, G. A., Fidlay, R. P., Kouri \& De Macedo, J. B. (Eds.), Debt stabilization and development: Essays in memory of Carlos DiazAlejandro (pp.80-102). Oxford and Cambridge, MA: Blackwell.

Sun, Y. (2004). "External Debt Sustainability in HIPC Completion Point Countries", IMF Working Paper.

Swiss National Bank Statistic. (2011). Switzerland International Investment Position in 2010. Retrieved from https://snb.ch/en/mmr/reference/iip_2010/source/iip_2010_12.en.pdf

Thangavelu, S.M., and G. Rajaguru (2004). Is There An Export or Import Led Productivity Growth in Rapidly Developing Asian Countries? A Multivariate VAR Analysis. Applied Economics, 36(10), 1083-1094.

Uzun, A., Karakoy, C., Kabadayi, B., \& Emsen, O. S. (2012). The Impacts of External Debt on Economic Growth in Transition Economics. Chinese Business Review, 11(5), 491-499.

Zaman, R., \& Muhammad Arslan (2014). The Role of External Debt on Economic Growth: Evidence from Pakistan Economy. Journal of Economics and Sustainable Development, 5(24), 140-147.

Zouhaier, H., \& Fatma, M. (2014). Debt and Economic Growth. International Journal of Economics and Financial Issues, 4(2), 440-448. 